\title{
Study on iron uptake of peach seedlings
}

\author{
Caifang $\mathrm{Wu}^{1}$, Bixia Zheng ${ }^{2}$, Xiao Zhang ${ }^{3}$, Xianmin $\mathrm{Xia}^{2}$, Xiong Zhou ${ }^{2}$ and Lijin Lin ${ }^{1 *}$ \\ ${ }^{1}$ Institute of Pomology and Olericulture, Sichuan Agricultural University, Chengdu, Sichuan, 611130, China \\ ${ }^{2}$ College of Horticulture, Sichuan Agricultural University, Chengdu, Sichuan, 611130, China \\ ${ }^{3}$ Qionglai Agricultural and Rural Bureau, Chengdu, Sichuan, 611530, China
}

\begin{abstract}
Hydroponic experiment was conducted to study the effect of peach seedlings (Prunus davidiana) grown in nutrient solution with different Iron $(\mathrm{Fe})$ concentration. The results showed that Fe deficiency could inhibit growth of peach seedlings, the roots and shoots biomass of peach in Fe-free treatment was significant lower than that of other treatments, except for the peach seedlings treated with $60 \mathrm{mg} / \mathrm{L} \mathrm{Fe}$. The peach grown seedlings in nutrient solution with different Fe concentration, Fe content in roots increased significantly, in stems decreased significantly, in leaves increased significantly, except for the peach treated with 20 and $60 \mathrm{mg} / \mathrm{L} \mathrm{Fe}$, there was a marked drop in total Fe content in leaves compared with control. These results indicated that appropriate amount of $\mathrm{Fe}$ ( $\mathrm{Fe}$ concentration was $20 \mathrm{mg} / \mathrm{L}$ ) could favour the growth of peach seedlings; and excessive $\mathrm{Fe}$ ( $\mathrm{Fe}$ concentration was $60 \mathrm{mg} / \mathrm{L}$ ) cloud have deleterious effects on peach seedlings. In conclusion, Fe concentration was greater than 0 and less than $60 \mathrm{mg} / \mathrm{L}$, which was suitable for peach growth, especially the peach seedlings treated with $20 \mathrm{mg} / \mathrm{L} \mathrm{Fe}$.
\end{abstract}

\section{Introduction}

Iron $(\mathrm{Fe})$ is an essential nutrient element for plants affecting plant growth and development [1]. Fe deficiency chlorosis is a common abiotic stress affecting plants [2], under Fe deficiency exhibited serious chlorotic symptoms with yellowing leaves and lower chlorophyll content, photosynthetic rate decreases, along with a reduction in plant growth and fruit quality [3-4]. Particularly, chlorosis in fruit crops is becoming more and more serious in recent years, which has been reported in apple, pear, peach and so on [5-7]. Therefore, the research of Fe deficiency in plants has been paid extensive attention in academic circles.

Some studies have discussed chlorosis in peach [5-9], peach seedlings were more sensitive to Fe deficiency [9], Fe-deficiency may alter the barrier properties of the leaf surface of peach, which can significantly affect leaf water relations, solute permeability and pest and disease resistance [2]. In this study, hydroponic experiment was conducted to study the effect of peach (Prunus davidiana) grown and the model of $\mathrm{Fe}$ accumulation in nutrient solution with different Fe concentrations.

\section{$2 \quad$ Materials and methods}

\subsection{Materials}

The seeds of peach were purchased from a market in Chengdu, Sichuan, China.

\subsection{Experimental design}

The experiments were conducted with Hoagland solution under greenhouse conditions at the Chengdu campus of Sichuan Agricultural University from February to April 2019. After breaking dormancy, the plump seeds were surface-sterilized and sown, and then these seedlings were transferred to plastic nutrition bowls containing quartz sand. Subsequently, selecting the seedlings germinated robustly in good trim (about $10 \mathrm{~cm}$ high), replenished a ration of water and nutrient solution to seedlings on a regular basis. The nutrient solution is divided into $\mathrm{Fe}$-containing and $\mathrm{Fe}-$ free, $\mathrm{Fe}$ concentration in the nutrient solution was set as follows: $2.5,5,10,20$, 30,40 and $60 \mathrm{mg} / \mathrm{L}$, the $\mathrm{Fe}-$ free nutrient solution was used as the control group. Each treatment repeated 3 times. The seedings were experienced the treatments for one month, the roots, stem, and leaves of each plant were separately harvested, blanched at $110{ }^{\circ} \mathrm{C}$ for $15 \mathrm{~min}$, dried at $75{ }^{\circ} \mathrm{C}$ until reaching a constant weight, and weighed. The dried vegetation was digested in $\mathrm{HNO}_{3} / \mathrm{HClO}_{4}$, the content of $\mathrm{Fe}$ was determined by spectrophotometric method using o-phenanthroline according to the methods described by Liu et al. [10].

\subsection{Statistical analysis}

Use Microsoft Excel 2010 and DPS 7.5 software for statistical analysis, data analysis by one-way ANOVA with least significant difference at $5 \%$ confidence level.

\footnotetext{
*Corresponding author's e-mail: 1lj800924@qq.com
} 
Translocation factor $=$ the Fe content of shoots/ the Fe content of roots [11].

\section{Results and discussion}

\subsection{Biomass of peach seedlings}

Table 1. Biomass of peach seedlings.

\begin{tabular}{cccccc}
\hline $\begin{array}{c}\text { Iron concentration } \\
(\mathrm{mg} / \mathrm{L})\end{array}$ & $\begin{array}{c}\text { Roots } \\
(\mathrm{g} / \text { plant })\end{array}$ & $\begin{array}{c}\text { Stems } \\
(\mathrm{g} / \text { plant })\end{array}$ & $\begin{array}{c}\text { Leaves } \\
(\mathrm{g} / \text { plant })\end{array}$ & $\begin{array}{c}\text { Shoots } \\
(\mathrm{g} / \text { plant })\end{array}$ & Root/shoot ratio \\
\hline 0 & $0.171 \pm 0.003 \mathrm{~d}$ & $0.463 \pm 0.011 \mathrm{~d}$ & $0.747 \pm 0.009 \mathrm{f}$ & $1.210 \pm 0.017 \mathrm{f}$ & 0.619 \\
2.5 & $0.199 \pm 0.004 \mathrm{c}$ & $0.436 \pm 0.005 \mathrm{e}$ & $0.934 \pm 0.019 \mathrm{~d}$ & $1.370 \pm 0.015 \mathrm{e}$ & 0.467 \\
5 & $0.213 \pm 0.006 \mathrm{~b}$ & $0.529 \pm 0.004 \mathrm{c}$ & $1.229 \pm 0.014 \mathrm{~b}$ & $1.758 \pm 0.018 \mathrm{c}$ & 0.430 \\
10 & $0.225 \pm 0.009 \mathrm{a}$ & $0.670 \pm 0.014 \mathrm{~b}$ & $1.471 \pm 0.016 \mathrm{a}$ & $2.140 \pm 0.005 \mathrm{a}$ & 0.455 \\
20 & $0.211 \pm 0.005 \mathrm{~b}$ & $0.739 \pm 0.008 \mathrm{a}$ & $1.224 \pm 0.019 \mathrm{~b}$ & $1.962 \pm 0.027 \mathrm{~b}$ & 0.604 \\
30 & $0.197 \pm 0.003 \mathrm{c}$ & $0.517 \pm 0.007 \mathrm{c}$ & $1.098 \pm 0.023 \mathrm{c}$ & $1.616 \pm 0.030 \mathrm{~d}$ & 0.471 \\
40 & $0.193 \pm 0.009 \mathrm{c}$ & $0.466 \pm 0.011 \mathrm{~d}$ & $0.894 \pm 0.019 \mathrm{e}$ & $1.361 \pm 0.030 \mathrm{e}$ & 0.522 \\
60 & $0.173 \pm 0.006 \mathrm{~d}$ & $0.434 \pm 0.006 \mathrm{e}$ & $0.718 \pm 0.015 \mathrm{f}$ & $1.152 \pm 0.021 \mathrm{~g}$ & 0.604 \\
\hline
\end{tabular}

Values are mean \pm SD $(n=3)$. Different lowercase letters indicate significant differences based on one-way analysis of variance in DPS 7.5 followed by the least significant difference test $(p<0.05)$.

Different Fe concentration had different impact on the growth of peach seedlings (Table 1). The roots biomass was markedly higher under Fe treatments than that of control, except the Fe concentration was $60 \mathrm{mg} / \mathrm{L}$. With the increase of Fe concentration, biomass accumulated to the root, when the Fe concentration was $10 \mathrm{mg} / \mathrm{L}$, roots biomass was the highest. Under Fe-containing conditions, 5, 10, 20 and $30 \mathrm{mg} / \mathrm{L}$ Fe treatments caused a marked increase of stems biomass, by $14.25 \%, 44.71 \%$, $59.61 \%$ and $11.66 \%$ respectively, compared with control, but no significant difference in $40 \mathrm{mg} / \mathrm{L} \mathrm{Fe}$ treatment and dropped significantly in 2.5 and $60 \mathrm{mg} / \mathrm{L}$ Fe treatments were observed. Fe could enhance the leaves biomass accumulation, and leaves biomass got the highest in peach treated with $10 \mathrm{mg} / \mathrm{L} \mathrm{Fe}$. Similar to the biomass of roots and leaves, the biomass of shoots biomass was the highest when the Fe concentration was $10 \mathrm{mg} / \mathrm{L}$, and 20 $\mathrm{mg} / \mathrm{L} \mathrm{Fe}$ treatments came next to it, which caused significant increases of shoots biomass by $76.86 \%$, $62.15 \%$ respectively, compared with control.

\subsection{Fe content in peach seedlings}

Total Fe content was examined in roots, stems and leaves of peach seedlings (Table 2). With increasing concentration of $\mathrm{Fe}$, the $\mathrm{Fe}$ content in roots remarkably increased, and showed a quick raise first and then decreased, the highest content of Fe in roots achieved $141.3 \mathrm{mg} / \mathrm{kg}$ when peach seedlings treated with $20 \mathrm{mg} / \mathrm{L}$ $\mathrm{Fe}$. The Fe content in stems was is different from the $\mathrm{Fe}$ content in roots, which apparently decreased under $\mathrm{Fe}-$ containing conditions. And the lowest content of $\mathrm{Fe}$ in stems was $27.25 \mathrm{mg} / \mathrm{kg}$, observed in $10 \mathrm{mg} / \mathrm{L} \mathrm{Fe}$ treatments. The Fe content in the leaves of peach were increased significantly, except for the peach treated with 20 and $60 \mathrm{mg} / \mathrm{L} \mathrm{Fe}$ compared with control. Under Fecontaining conditions, 10,20 and $60 \mathrm{mg} / \mathrm{L} \mathrm{Fe}$ treatments caused a significant decrease of the Fe content in shoots compared with control, while 2.5, 5, 30 and $40 \mathrm{mg} / \mathrm{L} \mathrm{Fe}$ treatments significantly increased the $\mathrm{Fe}$ content in shoots. Under Fe-free conditions, translocation factor was the highest (5.629); when Fe concentration was 20 $\mathrm{mg} / \mathrm{L}$, translocation factor was the lowest (0.351).

Table 2. Fe content in peach seedlings.

\begin{tabular}{cccccc}
\hline $\begin{array}{c}\text { Iron concentration } \\
(\mathrm{mg} / \mathrm{L})\end{array}$ & $\begin{array}{c}\text { Roots } \\
(\mathrm{mg} / \mathrm{kg})\end{array}$ & $\begin{array}{c}\text { Stems } \\
(\mathrm{mg} / \mathrm{kg})\end{array}$ & $\begin{array}{c}\text { Leaves } \\
(\mathrm{mg} / \mathrm{kg})\end{array}$ & $\begin{array}{c}\text { Shoots } \\
(\mathrm{mg} / \mathrm{kg})\end{array}$ & $\begin{array}{c}\text { Translocation } \\
\text { factor }\end{array}$ \\
\hline 0 & $14.15 \pm 0.464 \mathrm{~g}$ & $115.9 \pm 4.421 \mathrm{a}$ & $57.15 \pm 1.897 \mathrm{e}$ & $79.64 \pm 0.964 \mathrm{~d}$ & 5.629 \\
2.5 & $40.96 \pm 1.313 \mathrm{f}$ & $107.9 \pm 3.665 \mathrm{~b}$ & $73.97 \pm 2.442 \mathrm{~d}$ & $84.76 \pm 2.499 \mathrm{bc}$ & 2.069 \\
5 & $45.06 \pm 1.863 \mathrm{f}$ & $35.08 \pm 1.767 \mathrm{f}$ & $110.44 \pm 4.429 \mathrm{~b}$ & $87.77 \pm 2.760 \mathrm{~b}$ & 1.950 \\
10 & $97.21 \pm 2.822 \mathrm{~d}$ & $27.25 \pm 1.755 \mathrm{~g}$ & $87.48 \pm 2.793 \mathrm{c}$ & $68.65 \pm 2.018 \mathrm{e}$ & 0.707 \\
20 & $141.3 \pm 4.028 \mathrm{a}$ & $53.26 \pm 0.870 \mathrm{e}$ & $47.29 \pm 1.458 \mathrm{f}$ & $49.54 \pm 0.605 \mathrm{f}$ & 0.351 \\
30 & $133.8 \pm 5.256 \mathrm{~b}$ & $70.11 \pm 2.405 \mathrm{~d}$ & $134.1 \pm 3.896 \mathrm{a}$ & $113.6 \pm 1.882 \mathrm{a}$ & 0.849 \\
40 & $117.4 \pm 4.882 \mathrm{c}$ & $82.85 \pm 4.191 \mathrm{c}$ & $83.65 \pm 2.131 \mathrm{c}$ & $83.37 \pm 1.028 \mathrm{c}$ & 0.711 \\
60 & $61.58 \pm 2.430 \mathrm{e}$ & $55.25 \pm 1.020 \mathrm{e}$ & $37.17 \pm 1.742 \mathrm{~g}$ & $43.98 \pm 1.081 \mathrm{~g}$ & 0.715 \\
\hline
\end{tabular}

Values are mean \pm SD $(n=3)$. Different lowercase letters indicate significant differences based on one-way analysis of variance in DPS 7.5 followed by the least significant difference test $(p<0.05)$. 


\section{Conclusions}

$\mathrm{Fe}$ is involved in the synthesis of chlorophyll, under $\mathrm{Fe}$ deficiency exhibited serious chlorotic symptoms, and plant growth is restrained [12]. Most Fe stored in roots, remobilization of cell wall $\mathrm{Fe}$ in older leaves and roots has been evolved to increase the resistance to $\mathrm{Fe}$ deficiency [12]. In this study, Fe complete deficiency led to a higher TF (5.629), the ability of transferring Fe from roots to shoots of peach was improved. However, most Fe was transported from roots to stems, not leaves, so that led to the lowest total $\mathrm{Fe}$ content in roots (14.15 $\mathrm{mg} / \mathrm{kg})$, the highest total $\mathrm{Fe}$ content in stems (115.9 $\mathrm{mg} / \mathrm{kg}$ ) and lower total $\mathrm{Fe}$ content in leaves (57.15 $\mathrm{mg} / \mathrm{kg}$ ). Chlorophyll is positively correlated with leaf $\mathrm{Fe}$ status, lower total $\mathrm{Fe}$ content in leaves caused low chlorophyll content, plant growth was inhibited [13]. Fe deficiency could inhibit growth of peach seedlings, specific performances: the roots and shoots biomass of peach in Fe-free treatment was significant lower than that of other treatments, except for the peach treated with $60 \mathrm{mg} / \mathrm{L} \mathrm{Fe}$. Furthermore, Fe-free resulted in a higher shoot/root ratio, the shoots were inhibited more obviously than the roots.

And appropriate amount of Fe could favour the growth of plant, while excessive Fe retarded the growth of plant [14]. Under Fe-containing conditions, Fe content in roots as gradually decreased as the $\mathrm{Fe}$ increased, and in stems decreased significantly, in leaves increased significantly, except for the peach seedlings treated with 20 and $60 \mathrm{mg} / \mathrm{L} \mathrm{Fe}$, there was a marked drop in total $\mathrm{Fe}$ content in leaves compared to $\mathrm{Fe}$-free treatments. Concurrently, the roots and shoots biomass of peach seedlings under $\mathrm{Fe}$-containing conditions was significantly higher than that under $\mathrm{Fe}-$ free conditions, except for the peach seedlings treated with $60 \mathrm{mg} / \mathrm{L} \mathrm{Fe}$. These results indicated that appropriate amount of $\mathrm{Fe}(20$ $\mathrm{mg} / \mathrm{L} \mathrm{Fe}$ ) could favour the growth of peach; and excessive $\mathrm{Fe}(60 \mathrm{mg} / \mathrm{L} \mathrm{Fe})$ cloud have deleterious effects on peach seedlings.

Stated thus, it seemed that Fe concentrations were greater than 0 and less than $60 \mathrm{mg} / \mathrm{L}$, which was suitable for peach seedlings growth, especially the peach seedlings treated with $20 \mathrm{mg} / \mathrm{L} \mathrm{Fe}$.

\section{References}

1. Jain, A., Connolly, E.L. (2013) Mitochondrial iron transport and homeostasis in plants. Front. Plant Sci., 4: 348.

2. Fernández, V., Eichert, T., Del Río, V., LópezCasado, G., Heredia-Guerrero, J.A., Abadía, A., Heredia, A., Abadía, J. (2008) Leaf structural changes associated with iron deficiency chlorosis in field-grown pear and peach: physiological implications. Plant Soil, 311: 161-172.

3. Fuentes, M., Bacaicoa, E., Rivero, M., Zamarreño, Á.M., García-Mina, J.M. (2018) Complementary evaluation of iron deficiency root responses to assess the effectiveness of different iron foliar applications for chlorosis remediation. Front. Plant Sci., 9: 351.

4. Morales, F., Abadia, A., Belkhodja, R. (2010) Iron deficiency-induced changes in the photosynthetic pigment composition of fieldgrown pear (Pyrus communis L.) leaves. Plant Cell Environ., 17: 1153-1160.

5. Alvarez-Fernández, A., Melgar, J.C., Abadía, J., Abadía, A. (2011) Effects of moderate and severe iron deficiency chlorosis on fruit yield, appearance and composition in pear (Pyrus communis L.) and peach (Prunus persica (L.) Batsch). Environ. Experi. Bot., 71: 280-286.

6. Zhang, L.S., Wu, C.L., Wang, X.L., Ling J., Li, B.Z., Lu, D.Q. (2002) Effect of Fe-EDDHA on overcome iron-deficiency chlorosis and leaf elemental concentrations in peach orchards. Acta Agric. Boreali-Occidentalis Sin., 11: 60-62.

7. Xu, W.T., Gou, W.H., Qin, F., Ma, Z.Y, Zhou, S.X. (2011) Research progress of yellow leaf disease of woody plant. J. Jiangsu For. Sci. Tech., 38: 39-43.

8. Karagiannidis, N., Thomidis, T., Zakinthinos, G., Tsipouridis, C. (2008) Prognosis and correction of iron chlorosis in peach trees and relationship between iron concentration and Brown Rot[J]. Sci. Hortic., 118: 212-217.

9. Song, Z.Z., Yang, Y., Xu, J.L., Ma, R.J., Yu, M.L. (2014) Physiological and transcriptional responses in the iron-sulphur cluster assembly pathway under abiotic stress in peach (Prunus persica L.) seedlings. PCTOC, 117: 419-430.

10. Liu, H., Tian, Y.H. (2008) Determination of iron content in vegetables by o-Phenanthroline spectrophotometry. Chem. Bioeng., 25: 77-78.

11. Duman, F., Urey, E., Koca, F.D. (2015) Temporal variation of heavy metal accumulation and translocation characteristics of narrow-leaved cattail (Typha angustifolia L.). Environ. Sci. Pollut. Res., 22: 17886-17896.

12. Zhou, C., Liu, Z., Zhu, L., Ma, Z., Wang, J., Zhu, J. (2016) Exogenous melatonin improves plant iron deficiency tolerance via increased accumulation of polyamine-mediated Nitric Oxide. Int. J. Mol. Sci., 17: 1777.

13. Briat, J., Curie, C., Gaymard, F. (2007) Iron utilization and metabolism in plants. Curr. Opin. Plant Biol., 10: 276-282.

14. Cai, M.Z., Lin, X.Y., Lou, A.C, Zhang, Y.S. (2002) Effects of excessive $\mathrm{Fe}^{2+}$ on growth and physiological characters of rice. Plant Nutr. Fert. Sci., 8: 96-99. 